\title{
Forecasting of Net Asset Value of selected Environmental, Social and Governance (ESG) Mutual Funds in India using ARIMA Model
}

\author{
A. Akhileshwari, B. Kishore Babu, Dr. Rachana Professor
}

\begin{abstract}
:
After corporate governance and corporate social responsibility, ESG practises are the watchword in the Indian corporate environment. ESG is a far wider phrase than corporate governance and corporate social responsibility, as it encompasses a company's environmental, societal and corporate governance policies. ESG are the three pillars of performance that may be used to assess a company's influence on society and environmental sustainability. During the pandemic, these ESG-rated firms grew incredibly popular among investment portfolios. The investor's behaviour in these sustainable investments is also driven by the reputational benefits and a larger risk-reward ratio. It also assists investors in better understanding a firm and gaining insights into how it behaves, reacts, and evolves in response to numerous ESG aspects. Companies who do not adopt sustainable business strategies may find it difficult to raise both stock and loans in the future years. ESG compliance is required for every organisation that is operating well now and hopes to continue to do so in the future. Globally, there are over 3,300 ESG funds, which have quadrupled in the previous decade. This article studies about the sustainability rating, various ESG Mutual Funds in India, forecast the NAV of the ESG mutual funds using ARIMA.
\end{abstract}

Keywords: Environmental, Social and Governance (ESG), India, Net Asset Value (NAV), forecast, ARIMA

JEL Codes: C53, G11

\section{Introduction}

Background to the study:

Thematic mutual funds invest in the sectors that are specified with various themes such as rural development, energy conservation, environmental sustainability, corporate governance, export oriented, etc. These sectors of that specified theme are allocated $80 \%$ of the total assets of that thematic mutual fund. These funds are riskier than any other large cap mutual funds or diversified mutual funds. Sustainable Investing is one of them. It refers to the momentum these days. The year 2020 has seen a record of inflows into the ESG investing and the trend is still increasing, Inflows in ESG funds increased 76 percent to ₹3,686 crore in FY21 against ₹2,094 crore in FY20 (Source: The Hindu Business Line)

ESG stands for Environmental, Social, and Governance. It is a thematic mutual fund that invests in the companies which are compliant with factors that impact the environment (e.g.: to reduce carbon emissions, water and waste management, etc.), social (e.g.: employee welfare, gender equality, other societal causes), Corporate Governance (e.g.: regulations, grievances, etc.). This type of investing is cited as "sustainable" or "socially responsible" investing. These ESG mutual funds are regulated by SEBI (Securities Exchange Board of India).

\footnotetext{
A. Akhileshwari, e-mail: 2002550003@kluniversity.in

B. Kishore Babu, e-mail: kishorebabu11@kluniversity.in, KL Business School, KLEF, Vaddeswaram, Guntur, Andhra Pradesh

Rachana, e-mail: dr.rachna.saxena@gmail.com, Management Department, Jain University, Bangalore, Karnataka 
The individual letters of ESG considers:

- Environmental criteria, or the E in ESG, include the energy a business uses and wastes, the resources it requires, and the repercussions for living creatures as a result, as well as carbon emissions and climate change, are all examples of environmental criteria. Every business uses energy and resources, and every business has an impact on and is influenced by the environment.

- $S$ indicating the "social criteria," which relates to a company's relationships and reputation with people and institutions in the areas where it operates, as well as labour relations, diversity, and inclusion.

- G, or good governance, is a company's internal system of principles, controls, and procedures for governing itself, making rational decisions, obeying the code, and serving the interests of external stakeholders. Every business, which is a legal entity in and of itself, requires governance.

Fig 1 ESG Metrics:

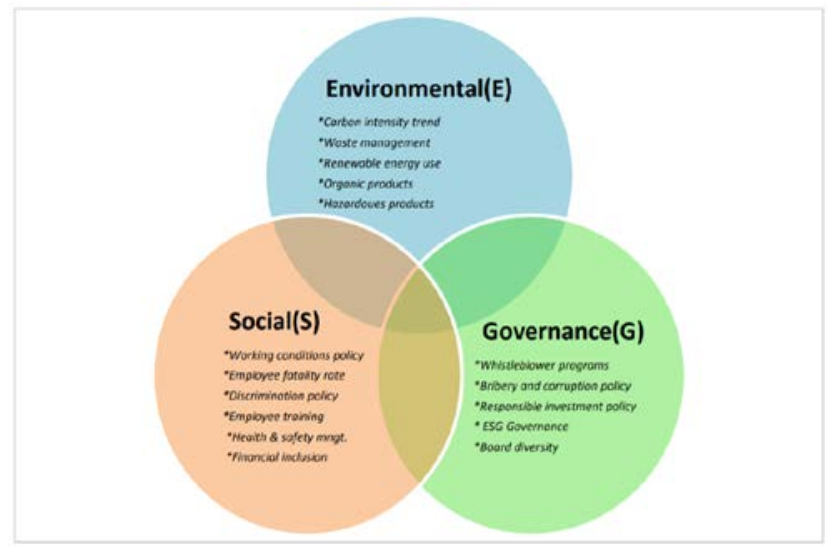

Source: nseindia.com

In this modern scenario, investors are evaluating the target companies not only based on financial parameters, but also non-financial parameters. i.e., investors are reassessing the conventional approach to investing, in which they consider not just company's profitability and valuation, but also the impact of their investment on the planet, such as whether the company does have a positive or negative impact on the environment and society. It is a fallacy that ESG investing is about segregating the companies that a company is good or bad based on the ESG factors. However, ESG is a framework that assists investors in better understanding a firm and gaining insights into how it behaves, reacts, and evolves in response to numerous ESG aspects. As a result of this, asset managers are forced to incorporate the ESG factors into their investment practices. Companies which are not following the sustainable business model will find tougher for raising debt and equity.

\section{Literature Review:}

Betty Moy Huber and Michael Comstock, Davis Polk \& Wardwell LLP (2017), opines that the sustainability rating is used as the base investor engagement with firms on environmental, social, and governance (ESG) issues. This article studies about the ESG rating agencies and also provides information on the ESG ETFs and portfolios offered by various asset managers.

Justyna Przychodzen, Fernando Gómez-Bezares, Wojciech Przychodzen and Mikel Larreina (2016) contemplated that the Sustainable investing has three pillars which encompass strategies to generate long-term financial returns while having a positive societal impact. The study, which is based on a survey of bank-affiliated fund managers in five countries, found that 
ESG problems are becoming more important in their short-term investment decision-making process and are seen as a good safeguard against extra business risk with the help of ANOVA.

Ms. Sejal Shah(2018), posited that investors seek returns from their investments in firms, but not at the cost of companies' reckless business practises that affect the environment and people, and also to be ethical and truthful while disclosing their financial performance. This study aims to explain the different aspects of socially responsible investing and its significance in India, with a particular focus on India's ESG-linked investment environment. The study suggested that companies must follow implement the ESG practices meticulously. It also suggested that the companies must give voluntary compliance of their ESG practices

Dr. A. Anis Akthar Sulthana Banu, Dr.T.S. Bhuvaneswari , Dr. Sajida Begum.K opined that an ESG fund scheme allows a socially aware investor to invest directly in financial markets or through investment tools such as mutual funds. It assesses the performance of SBI Magnum Mutual Fund schemes in comparison to benchmark indexes, as well as recommending an effective ESG portfolio for improved NAV and investor retention.

Helena Naffa, Ma'te' Fain posited that ESG factors are becoming more widespread in portfolio investment strategies, attracting more funds from investors who want to align their investing principles with the United Nations Principles for Responsible Investments' Sustainable Development Goals (SDGs). The study examines the risk-adjusted financial performance of ESG-themed megatrend investing strategies in global stock markets, covering nine ESG themes.

Gunnar Friede, Timo Busch \& Alexander Bassen posited that the financial impacts of ESG standards are still poorly understood. The study gathers all primary and secondary data from prior academic review studies that have been supplied. The findings demonstrate that the business case for ESG investment is empirically sound. A nonnegative ESG-CFP relationship is seen in almost $90 \%$ of investigations.

Emiel van Duuren, Auke Plantinga, and Bert Scholtens investigated how conventional asset managers incorporate environmental, social, and governance (ESG) considerations into their investing process, based on international survey among fund managers. Many conventional fund managers have already integrated responsible investing characteristics into their investment process, demonstrating that ESG investing is quite comparable to fundamental investing.

Fernando Munoz, Maria Vargas, and Isabel Marco examine the financial performance and management abilities of a group of socially responsible (SR) mutual funds from the United States and Europe. The outcomes for green fund managers are compared to those for traditional and other types of SR mutual fund managers. It is found that green funds do not perform less than other types of SR mutual funds.

\section{Objectives:}

To understand the components and process of sustainability rating

To study about various ESG Mutual Funds in India.

To forecast the NAV of the ESG mutual funds using ARIMA

\section{Net Asset Value:}

The value of a fund's assets minus value of its liabilities per unit is known as net asset value (NAV). It is commonly linked with mutual funds, and it aids in determining if the fund is overvalued or undervalued. NAV history analysis is a widespread technique among knowledgeable investors and considers it to be one of the best metrics of mutual fund performance.

In the case of open-ended mutual funds, NAV is essential since it determines the fund's value that an investor would be entitled to at the time of withdrawal. The price per unit is determined, 
in case of a close-end fund by the market, which may be lower or higher than the NAV. For most mutual funds, the NAV is calculated continually during market hours. As a result, investors may always know how their mutual fund is performing, and they can purchase or sell mutual funds at any moment.

\section{Sustainability Rating:}

Sustainability rating is used to evaluate an organisation's environmental, social values and performance. Most public and private companies are evaluated by these sustainability rating agencies to measure how well a company manages to maintain equitable balance of these three dimensions and the financial performance of the company. It is anticipated that the company with a relatively higher score has a lower risk of bad financial performance, and also poor decision making of the ESG criteria. This may aid in discovering opportunities for additional innovation, as well as making the company more appealing to employees and other stakeholders, as well as lessening the effect of rigorous regulations and standards. There is no uniform definition of what defines a "socially responsible" firm, there are many different approaches to assess and rank them.

Investors, stakeholders, applicants, as well as businesses and financial institutions, utilise these sustainability ratings. Each of these users has a unique perspective on how to use these ratings. Sustainability ratings are used by investors to identify reputational concerns, as well as to compare and manage their portfolios. These sustainability ratings are used by stakeholders to motivate themselves to work with their organisations to strengthen ties to attain internationalisation. The sustainability ratings are used by applicants (companies) to get an independent assessment as well as to convey their relative risk to attract investors and shareholders. Financial institutions use the sustainability rating to analyse counterparty risks, i.e., to decide whether to lend/invest in a certain firm.

These rankings differ from one provider to another provider, in terms of methodology or scope or any other. There are many ESG data providers. The ESG rating agencies are of two models: Investor pay model, Applicant Pay Model. Under the Investor Pay model, the agencies rate each of the companies and provide the list of investable companies' data to the investors. Here, the investor must pay the rating agency for providing the data. Under the Applicant Pay Model, companies obtain their independent rating to assess their relative risk. Some of the ESG rating agencies in India are CRISIL, MSCI, Acuite, Sustainalytics, etc. Each of these rating agencies has a different rating scale and methodology. The data is collected from various sources like companies' annual reports and websites, sustainability reports, stock exchange filings, news reports and other third-party data providers.

The primary issues addressed by these rating agencies are divided into three categories: environment, society, and corporate governance, which are further, divided by industry and then further divided into numerous essential elements in accordance with the industry. Some of the ESG Carbon emissions, energy efficiency, waste intensity via waste management, product life cycle, supply chain, employee happiness, data security, employee equity and equality, employee safety, community engagement, labour practises, accounting disclosure, company ethics, board structure, tax structures and other metrics are used in the sustainability rating.

The ESG Rating Agencies in India are as follows:

CRISIL: CRISIL is the first credit rating agency established in India and is concise for Credit Rating Information Services of India Limited. It is a global analytical company, which operates from 7 research centres, Argentina, China, India, Poland and across several time zones and languages. It helps in taking better financial decisions by analysing \& providing insights about the financial performance of the companies. CRISIL Rating aids issuers and borrowers in better access to capital by identifying various funding and investment options. The ratings also help the financial institution in lowering its cost of funding.

Rating scale: The scale runs from 0 to 100, with 100 being the highest. 
Methodology: CRISIL ESG ratings are evaluated based on the publicly available information (both qualitative and quantitative) by the companies. CRISIL's ESG framework contains about 100 different ESG parameters across the three aspects. The data is collected from various sources like companies' annual reports and websites, sustainability reports, stock exchange filings, news reports and other third-party data providers.

MSCI: Acronym for Morgan Stanley Capital Information, headquartered in New York was launched in the year 2010. It is the world's largest ESG Indices provider with over 1,500 equity and fixed income ESG Indices. The MSCI BRIC, MSCI World, and MSCI EAFE Indexes are all published by the MSCI.

Rating Scale: AAA, AA, A are ranked as leaders, BBB, BB are ranked as average, and B, CCC are classified as laggards on the AAA-CCC scale.

Methodology: The three pillars of ESG are divided into ten themes by the MSCI rating methodology, namely climate change, natural resources, pollution \& waste, environmental opportunities, human capital, product liability, stakeholder opposition, social opportunities, corporate governance, and corporate behaviour, and these themes are further divided into 37 key issues in the ESG sector.

Acuite: Acuite, India's first ESG firm was founded by Acuite Ratings \& Research Limited. It is a bond and bank loan rating firm that is registered with SEBI and is accredited by the RBI. Acuité Ratings has given credit ratings to over 8,600 companies in more than 200 industries. The company has created ESG evaluation tools and an electronic workflow in addition to ESG ratings.

Methodology: ESG risk AI employs a rigorous assessing technique that divides data into three levels: key issue, theme, and category, each of which is the next level of aggregation for hierarchical risk assessment. ESG Risk AI examines a company's ESG performance across three categories, 19 themes, and 35 significant problems. The results are based on a thorough examination of 739 data points that are combined into 525 indicators.

Sustainalytics: Subsidiary of Morning star Company established in the year 1992, headquartered in Amsterdam, Netherlands, is a leading independent ESG risk and research analytics company with 16 offices around the world. Sustainalytics' ratings can also be accessed through some of the eminent third-party platforms such as Bloomberg, Factset, IHS Markit.

Rating Scale: The risk rating is measured on a five-point scale where negligible (0-10), low (10-20), medium (20-30), high (30-40) and severe (40+)

Methodology: The major concerns addressed by Sustainalytics are grouped into three categories: environment, society, and corporate governance, which are further segregated by industry. At least 70 critical aspects from each industry are included.

\section{Methods}

\section{ARIMA:}

Autoregressive Integrated Moving Average (ARIMA) is a technique for analysing and forecasting time series data that was developed by a group of electrical engineers in the 1930s and subsequently developed in the 1970s by George Box and Gwilym Jenkins (hence, it is also known as Box-Jenkins model). It is commonly used to forecast the future using historical data. This model is a type of regression analysis that determines the dependent variable's tenacity in comparison to the other parameters. It is a type of regression analysis that determines the dependent variable's tenacity in comparison to the other parameters. 
Fig 2 Notation for ARIMA:
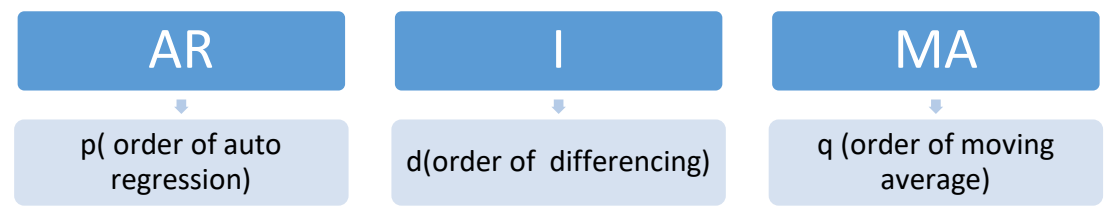

Source: Author’s own

- The Partial Autocorrelation graph is used to determine the number of autoregressive terms (p).

- $\mathrm{d}$ is the number of non-seasonal differences that must be present for stationarity to be achieved.

- The Autocorrelation graph is used to determine the order of moving average (q).

The ARIMA model is employed to understand the past, assess the present, and forecast the future. Under some circumstances, such as technological breakthroughs or financial crises, this approach might become absolutely erroneous.

\section{Steps for building ARIMA Model in Python:}

$\rightarrow$ Step 1: The foremost step for building ARIMA is to ensure that the time series data is stationarized, especially if it has trend or seasonality components. This can be done by using Augmented Dickey-Fuller test (ADF Test) and Kwiatkowski-Phillips-SchmidtShin test (KPSS test).

$\rightarrow$ Step 2: If the data is not stationary, differencing must be done. Logarithms can help in making the data stationary by stabilisation of the mean and variance. This aids in the stabilisation of the time series data's mean and variance, eliminating the trend/seasonality. Logarithms can help in the stabilisation of the mean and variance.

$\rightarrow$ Step 3: The next step is to validate the test through train-test validation split to test the accuracy of the model.

$\rightarrow$ Step 4: ACF and PACF plots are used to determine the AR (p) and MA (q) values.

$\rightarrow$ Step 5: Build the model and set the number of periods for forecasting.

$\rightarrow$ Step 6: The final step is to compare the forecasted values with the actual values in the validation sample.

\section{Data Analysis:}

The data is taken from the website of Association of Mutual Funds in India (AMFI). Seven ESG Mutual funds were taken for analysis. ARIMA Model is being built in Python for forecasting the NAV of each of the ESG Mutual Funds.

\section{Results}

\section{SBI Magnum Equity ESG Fund:}

On November 27, 2006, SBI Mutual Fund House launched the SBI Magnum Equity ESG Mutual Fund, an open-ended mutual fund programme. The NIFTY 100 ESG TRI is used to measure its performance. Companies are scored based on parameters of companies' ESG, and the weightage is decided on the basis of its score. This fund invests 80-100 percent of its assets in equity and associated securities, with the remaining 0-20 percent in other stocks, bonds, and money market instruments. The Current Net Asset Value as of 01 Sep 2021 is Rs 160.9011 
Forecasting of Net Asset Value of selected Environmental, Social and Governance (ESG) Mutual Funds in India using ARIMA Model

Model: ARIMA $(3,0,2)$

Sample period: 01-01-2021 to 01-09-2021

Forecast period: 365 days

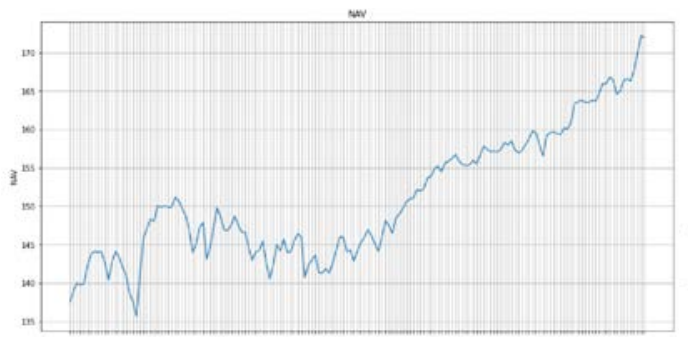

Fig 3: Graph showing actual NAV of SBI ESG Mutual Fund

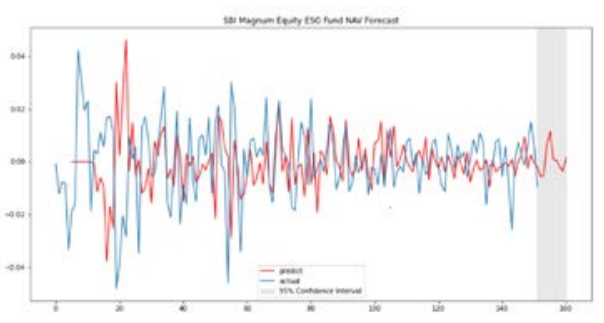

Fig 4: Graph showing actual and forecasted NAV of SBI ESG Mutual

\section{Quantum India ESG Equity Fund:}

Launched on Jul 12, 2019, is an open ended thematic equity fund by the Quantum Mutual Fund House. The NIFTY 100 ESG TRI is used to measure its performance. This mutual fund is suitable for the investors who are seeking for long term capital appreciation. The Current Net Asset Value as of 01 Sep 2021 is Rs 16.7900

Model: ARIMA $(0,1,0)$

Sample period: 01-01-2021 to 01-09-2021

Forecast period: 365 days

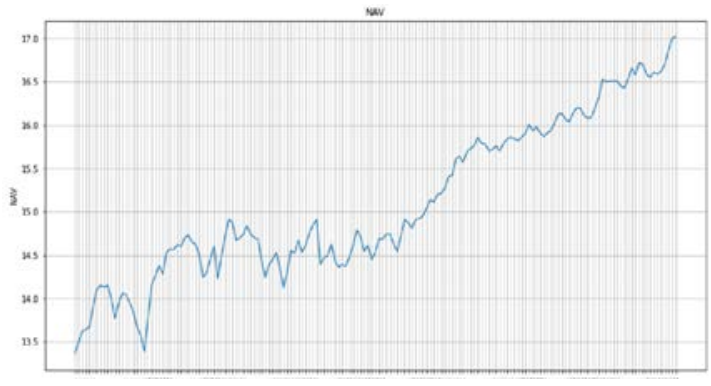

Fig 5 Graph showing actual NAV of Quantum ESG Mutual Fund

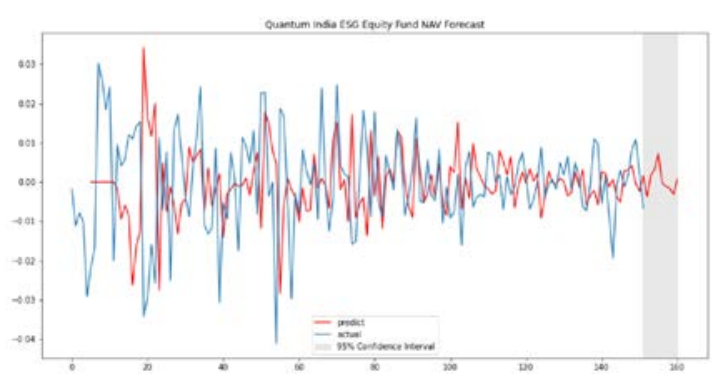

Fig 6 Graph showing actual and forecasted NAV of Quantum ESG

\section{Aditya Birla Sun Life ESG Fund:}

Launched on Dec 24, 2020 is an open ended thematic equity fund by the Birla Sun Life Mutual Fund House. The NIFTY 100 ESG TRI is used to measure its performance. The Current Net Asset Value as of 01 Sep 2021 is Rs 12.7600

Model: ARIMA $(3,1,0)$

Sample period: 01-01-2021 to 01-09-2021

Forecast period: 365 days 


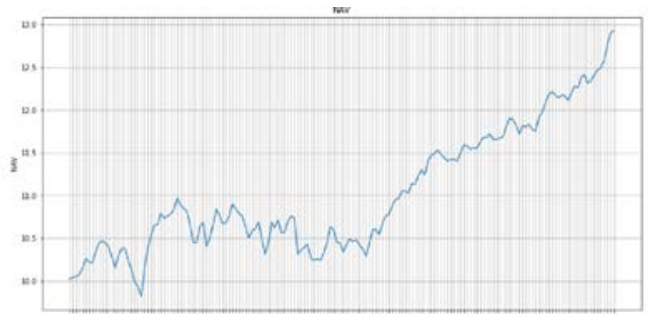

Fig 7 Graph showing actual NAV of Aditya Birla ESG Mutual Fund

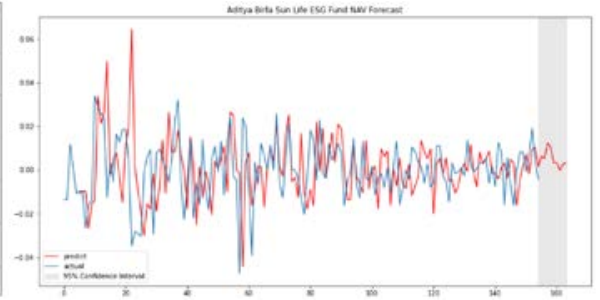

Fig 8 Graph showing actual and forecasted NAV of Aditya Birla

\section{ICICI Prudential ESG Fund:}

Launched on Oct 09, 2020, is an Open-ended Thematic Equity mutual fund by the ICICI Prudential Mutual Fund House. The NIFTY 100 ESG TRI is used to measure its performance. The Current Net Asset Value as of 01 Sep 2021 is Rs 13.7600. This mutual fund is suitable for the investors who are seeking for long term SIP and wealth creation.

Model: ARIMA $(3,1,0)$

Sample period: 01-01-2021 to 01-09-2021

Forecast period: 365 days

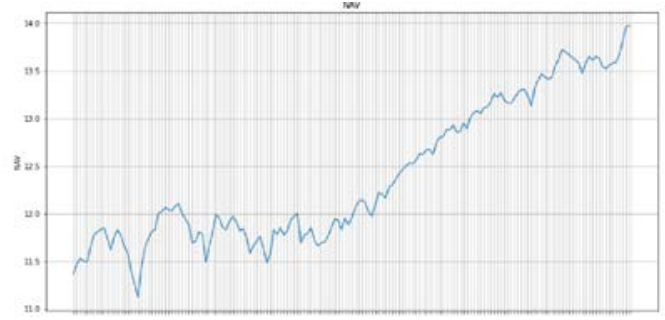

Fig 9 Graph showing actual NAV of ICICI Prudential ESG Mutual Fund

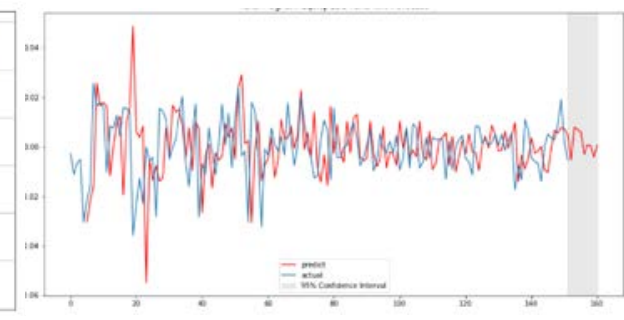

Fig 10 Graph showing actual and forecasted NAV of ICICI Prudential

\section{Mirae Asset ESG Sector Leaders Fund of Fund:}

Launched on Nov 18, 2020, is an Open-ended Thematic Equity mutual by Mirae Asset Mutual Fund House. Nifty 100 ESG Sector Leaders Total Return Index (TRI Index) is used to measure its performance. The Current Net Asset Value as of 01 Sep 2021 is Rs 12.9750. This mutual fund is suitable for the investors who are seeking for long term capital appreciation.

Model: ARIMA $(1,0,1)$

Sample period: $01-01-2021$ to 01-09-2021

Forecast period: 365 days

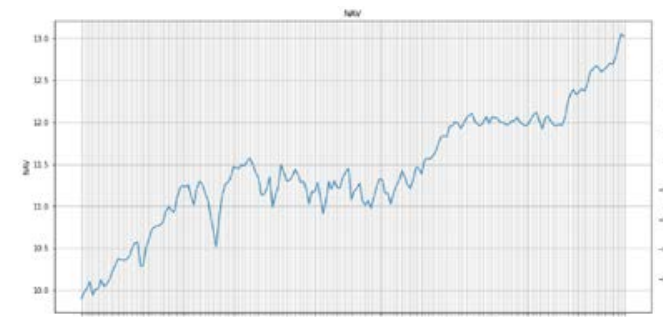

Fig 11 Graph showing actual NAV of Mirae Asset ESG Mutual Fund

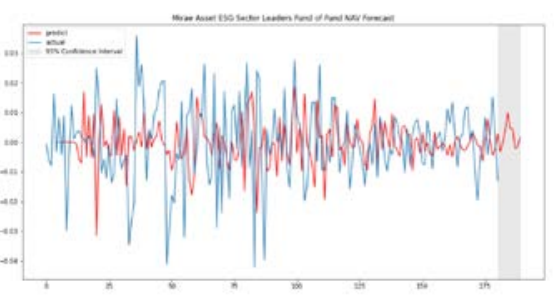

Fig 12 Graph showing actual and forecasted NAV of Mirae Asset 
Forecasting of Net Asset Value of selected Environmental, Social and Governance (ESG) Mutual Funds in India using ARIMA Model

\section{Quant ESG Equity Fund:}

Launched on Nov 06, 2020, is Open-ended Thematic equity mutual fund scheme by Quant Mutual Fund House. The NIFTY 100 ESG TRI is used to measure its performance. The Current Net Asset Value as of 01 Sep 2021 is Rs 17.5334.

Model: ARIMA $(1,0,0)$

Sample period: 01-01-2021 to 01-09-2021

Forecast period: 365 days

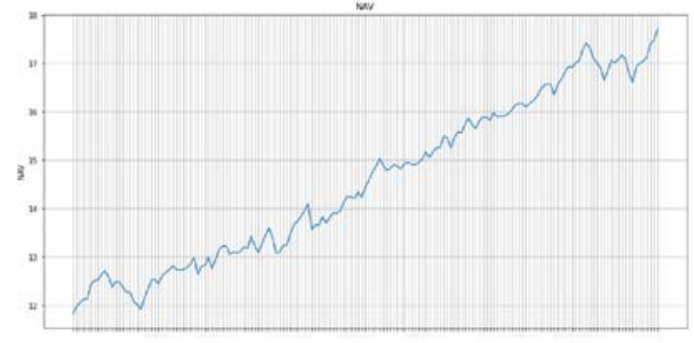

_ Fig 13 Graph showing actual NAV of Quant ESG Mutual Fund

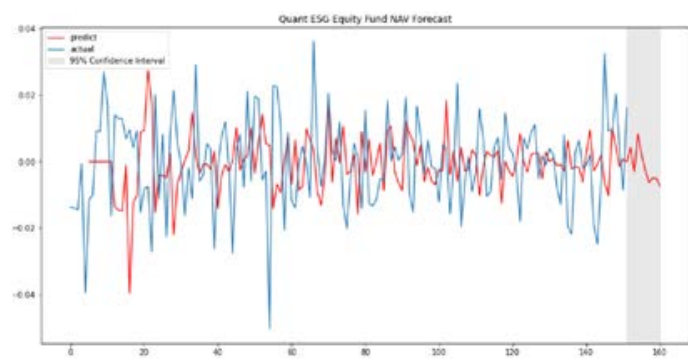

Fig 14 Graph showing actual and forecasted NAV of Quant ESG

\section{Axis ESG Equity Fund:}

Launched on Feb 12, 2020, is an Open-ended Thematic equity mutual fund by Axis Mutual Fund House. The NIFTY 100 ESG TRI is used to measure its performance. The Current Net Asset Value as of 01 Sep 2021 is Rs 16.3200.

Model: ARIMA $(2,1,0)$

Sample period: $01-01-2021$ to $01-09-2021$

Forecast period: 365 days

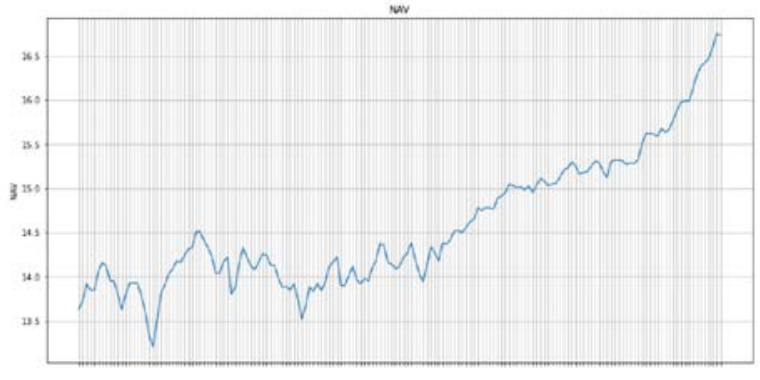

Fig 15 Graph showing actual NAV of Axis ESG Mutual Fund

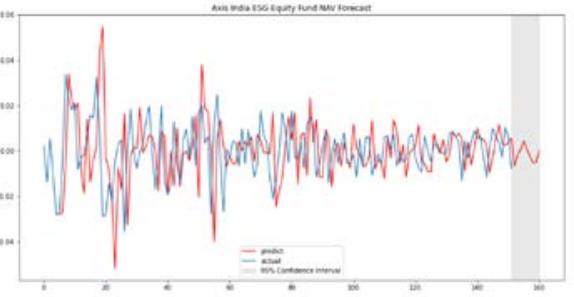

Fig 16 Graph showing actual and forecasted NAV of Axis ESG 


\section{Findings:}

Table 1

\begin{tabular}{|c|c|c|c|c|c|c|c|}
\hline $\begin{array}{l}\text { Name of the } \\
\text { Mutual Fund }\end{array}$ & $\begin{array}{c}\text { SBI } \\
\text { Magn } \\
\text { um } \\
\text { ESG }\end{array}$ & $\begin{array}{c}\text { Quant } \\
\text { um } \\
\text { ESG }\end{array}$ & $\begin{array}{c}\text { Aditya } \\
\text { Birla } \\
\text { Sunlife } \\
\text { ESG }\end{array}$ & $\begin{array}{c}\text { ICICI } \\
\text { Prudentia } \\
\text { I ESG }\end{array}$ & $\begin{array}{c}\text { Mirae } \\
\text { Asset } \\
\text { ESG }\end{array}$ & $\begin{array}{l}\text { Quant } \\
\text { ESG }\end{array}$ & $\begin{array}{l}\text { Axis } \\
\text { ESG }\end{array}$ \\
\hline ME & $\begin{array}{c}-0.000 \\
8\end{array}$ & $\begin{array}{c}-0.0006 \\
4\end{array}$ & 0.000399 & 0.000039 & -0.0001 & -0.0010 & $\begin{array}{c}-0.000 \\
2\end{array}$ \\
\hline RMSE & $\begin{array}{c}0.018 \\
83\end{array}$ & $\begin{array}{c}0.0165 \\
3\end{array}$ & 0.01884 & 0.01628 & 0.01565 & 0.01729 & $\begin{array}{c}0.0173 \\
8\end{array}$ \\
\hline MAPE & $\begin{array}{c}1.907 \\
3\end{array}$ & 2.5465 & 13.5955 & 3.1023 & 2.4557 & 3.0325 & $\begin{array}{c}12.263 \\
7\end{array}$ \\
\hline Ljung-Box & 0.24 & 0.0016 & -1.60 & -2.45 & $\begin{array}{l}-0.02 \\
\end{array}$ & $\begin{array}{l}-0.08 \\
\end{array}$ & 1.43 \\
\hline $\begin{array}{c}\text { Growth rate } \\
\text { as on Sept 01, } \\
2021\end{array}$ & $\begin{array}{c}25.02 \\
334\end{array}$ & $\begin{array}{c}27.395 \\
2\end{array}$ & 28.4011 & $\begin{array}{l}22.86 \\
-\end{array}$ & 20.47 & 49.73 & 22.74 \\
\hline $\begin{array}{c}\text { Forecasted } \\
\text { NAV growth } \\
\text { rate }\end{array}$ & $\begin{array}{c}42.82 \\
54\end{array}$ & $\begin{array}{c}41.828 \\
3\end{array}$ & 56.9806 & $\begin{array}{l}53.77 \\
-\end{array}$ & 32.14 & 68.45 & 64.06 \\
\hline
\end{tabular}

Source: Author's own

Interpretation of results:

The overall average growth rate of ESG mutual funds is 28.1 percent as of September 01,2021, and the average predicted growth rate for the following 365 days is 51.4 percent.

ME (Mean Error): For all the funds, in the analysis, the mean error is low, indicating that the discrepancy between actual and predicted values is minimal.

RMSE (Root Mean Squared Error): The Root Mean Squared error, which refers to the standard deviation of the observed and forecasted values, is also low for all the mutual funds when compared to other models

MAPE (Mean Absolute Percentage Error): The MAPE is less than $10 \%$, for all the mutual funds except Aditya Birla Sunlife ESG and Axis ESG mutual funds, indicating that the model is highly accurate for forecasting. For Aditya Birla Sunlife ESG and Axis ESG the MAPE is in between $10-20 \%$, indicating it is a good forecasting.

Each ESG Mutual Fund has a better growth rate from 1 January 2021 to September 1, 2021. The forecasted growth percentage is likewise higher, except for Aditya Birla Sunlife ESG Mutual Funds and Axis ESG Mutual funds.

Therefore, by integrating new data, investors may use this model to analyse and anticipate the NAV of their portfolios. This may change if there are any uncertainties, such as a financial 
Forecasting of Net Asset Value of selected Environmental, Social and Governance (ESG) Mutual Funds in India using ARIMA Model

crisis or technological advances, but this sturdy model may be utilised to make precise predictions.

\section{Conslusion}

ESG mutual funds are gaining wide acceptance these days. The notion that sustainability and profitability cannot coexist is no longer valid. The global financial crisis, the onset of COVID19, climate change awareness, ethics and values, environmental consciousness, regulatory environment, reduced risk, and other reasons are currently driving forces for ESG investments around the world. Because sustainable investing (ESG investment) is still a novel phenomenon in India, there is a misconception that it will not yield better returns. According to several research, there is no discernible difference in profitability between the sustainable and conventional investments. Other barriers like lack of knowledge and education regarding these funds, unfavourable risk and return views, and so forth. Therefore, the investment managers should become more deliberate about the sustainable investment about how they can include the Environmental, Social, and Governance factors into their investment strategies.

\section{Future Scope:}

The MAPE for Aditya Birla Sunlife ESG Mutual Funds and Axis ESG Mutual Funds is greater than $10 \%$, indicating that the model fitted is not optimal, according to the analysis. The objective of future study will be to find the best-fit model for such mutual funds.

\section{Acknowledgement}

The paper was presented at the AICTE International Conference on Circular Economy, Management and Industry, Bharati Vidyapeeth's Institute of Management Studies and Research, Navi Mumbai, and Apeejay School of Management, Dwarka, Delhi, India. October 2021

\section{References}

(n.d.). Retrieved from SBI Magnum ESG- economic times:

https://economictimes.indiatimes.com/sbi-magnum-equity-esg-fund/mffactsheet/schemeid190.cms

Acuité launches India's first ESG Rating Company: ESG risk - assessments \& insights. (2021). Retrieved from https://www.acuite.in/Acuite-launches-Indias-first-ESG-ratingcompany-11-1-20.htm

Aditya birla sunlife esg mutual funds. (n.d.). Retrieved from https://economictimes.indiatimes.com/aditya-birla-sun-life-esg-fund--regularplan/mffactsheet/schemeid-41219.cms

AMFI India. (n.d.). Retrieved from https://www.amfiindia.com/

Atkins, B. (2021). ESG metrics: A path forward for companies. Retrieved from https://www.forbes.com/sites/betsyatkins/2020/10/01/esg-metrics-a-path-forward-forcompanies/?sh=41ffa5ca76da

Axis esg mutual funds. (n.d.). Retrieved from https://economictimes.indiatimes.com/axis-esgequity-fund--regular-plan/mffactsheet/schemeid-40534.cms

Banu, A. A., Bhuvaneswari, T., \& BEGUM, S. (2021). A Study On The Sustainable Investment Funds With Sepcial Reference To State Bank Of India Esg Mutual Fund Shcemes. Turkish Journal of Computer and Mathematics Education (TURCOMAT), 12(6), 261-266.

Comstock, M., Huber, B. M., Polk, D., \& LLP, W. (n.d.). ESG Reports and Ratings: What They Are, Why They Matter. Retrieved from etrieved from Harvard Law School Forum on Corporate Governance: https://corpgov.law.harvard.edu/2017/07/27/esg-reports-and-ratingswhat-they-are-why-they-matter/ 
CRISIL ESG Compendium. (n.d.). Retrieved from https://www.crisil.com/en/home/what-wedo/financial-products/crisil-esg-compendium.html

Duuren, E. V., Plantinga, A., \& Scholtens, B. (n.d.). ESG integration and the investment management process: Fundamental investing reinvented. Journal of Business Ethics, 138(3), 525-533.

ESG investing: ESG Ratings. (n.d.). Retrieved from https://www.msci.com/our-solutions/esginvesting/esg-ratings

ESG reporting guide. (n.d.). Retrieved from https://www.nasdaq.com/ESG-Guide

ESG Reporting Guide 2.0. (2019). Retrieved from

https://www.nasdaq.com/docs/2019/11/26/2019-ESG-Reporting-Guide.pdf

ESG risk ratings. (n.d.). Retrieved from https://www.sustainalytics.com/corporatesolutions/esg-risk-ratings

ESG thematic funds: Invest in top-performing ESG themed funds in India. (n.d.). Retrieved from https://www.etmoney.com/mutual-funds/equity/thematic-esg/78

Friede, G., Busch, T., \& Bassen, A. (2015). ESG and financial performance: aggregated evidence from more than 2000 empirical studies. Journal of Sustainable Finance \& Investment, 5(4), 210-233.

ICICI Prudential esg fund. (n.d.). Retrieved from https://economictimes.indiatimes.com/iciciprudential-esg-fund/mffactsheet/schemeid-41125.cms?from=mdr

Mirae Asset ESG Mutual funds. (n.d.). Retrieved from

https://economictimes.indiatimes.com/mirae-asset-esg-sector-leaders-fof--regularplan/mffactsheet/schemeid-41158.cms

Muñoz, F., Vargas, M., \& Marco, I. (2013). Environmental mutual funds: Financial performance and managerial abilities. Journal of Business Ethics.

Naffa, H., \& Fain, M. (2020). Performance measurement of ESG-themed megatrend investments in global equity markets using pure factor portfolios methodology. Plos one, 15(12), e0244225.

Przychodzen, J., Gómez-Bezares, F., Przychodzen, W., \& Larreina, M. (2016). ESG Issues among fund managers-Factors and motives. Sustainability, 8(10), 1078. mdpi.

Quant ESG Mutual Fund. (n.d.). Retrieved from https://economictimes.indiatimes.com/quantesg-equity-fund--regular-plan/mffactsheet/schemeid-41163.cms

Quantum India ESG Equity Fund. (n.d.). Retrieved from

https://economictimes.indiatimes.com/quantum-india-esg-equity-fund--regular-

plan/mffactsheet/schemeid-40009.cms

Sangarshanan. (n.d.). Time series forecasting-arima models. Retrieved from https://towardsdatascience.com/time-series-forecasting-arima-models-7f221e9eee06

SBI Magnum esg equity. (n.d.). Retrieved from https://economictimes.indiatimes.com/sbimagnum-equity-esg-fund/mffactsheet/schemeid-190.cms

Shah, M. S. (2018). A Study of Essence of Socially Responsible Investment and Environmental, Social and Governance (ESG)-linked Investment Market in India. International Journal for Research Trends and Innovation, 5. 